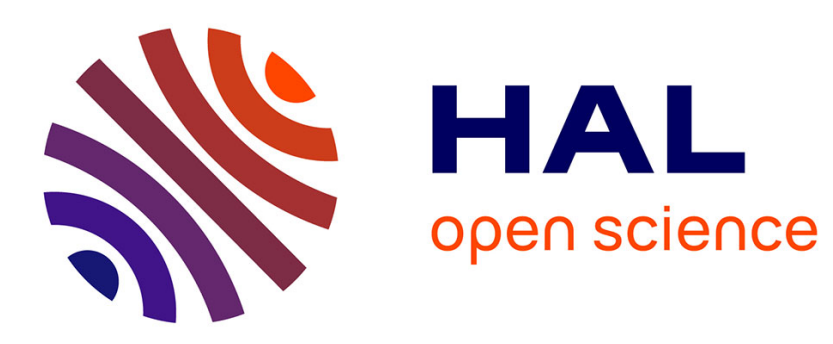

\title{
Self-efficacy, goals, and job search behaviors
}

Isabelle Fort, Flora Jacquet, Naïs Leroy

\section{To cite this version:}

Isabelle Fort, Flora Jacquet, Naïs Leroy. Self-efficacy, goals, and job search behaviors. Career Development International, 2011, 16 (5), pp.469-481. 10.1108/13620431111168886 . hal-01791013

\section{HAL Id: hal-01791013 https://hal-amu.archives-ouvertes.fr/hal-01791013}

Submitted on 14 May 2018

HAL is a multi-disciplinary open access archive for the deposit and dissemination of scientific research documents, whether they are published or not. The documents may come from teaching and research institutions in France or abroad, or from public or private research centers.
L'archive ouverte pluridisciplinaire $\mathbf{H A L}$, est destinée au dépôt et à la diffusion de documents scientifiques de niveau recherche, publiés ou non, émanant des établissements d'enseignement et de recherche français ou étrangers, des laboratoires publics ou privés. 
Self-efficacy, goals, and job search behaviors

Isabelle Fort, Flora Jacquet and Naïs Leroy

Aix-Marseille University

Corresponding author:

Isabelle Fort, $\mathrm{PhD}$

* Université d'Aix-Marseille

Centre de Recherche en Psychologie de la Connaissance du Langage et de l'Emotion

(PsyCLE)

29 avenue Robert Schuman

13621 Aix-en-Provence Cedex 1

France

e-mail: isabelle.fort@univ-provence.fr 
SELF-EFFICACY, GOALS AND JOB SEARCH BEHAVIORS

\begin{abstract}
Purpose - This study examined the relationship between job search self-efficacy, employment goals, job search planning, job search behaviors and effort allocated to job search. We expected that employment goals would mediate the effect of job search self-efficacy on job search planning, job search behaviors and effort allocated to job search.
\end{abstract}

Design / methodology / approach - One hundred participants completed measures of these concepts.

Findings - Regression analyses did not confirm our hypotheses. Contrary to expectations, employment goals did not mediate the path between self-efficacy, job search planning, job search behaviors and effort allocated to job search. Instead, self-efficacy directly influenced job search planning and job search behaviors. Results are discussed with reference to previous studies and to methodological choices.

Originality / value - Few studies have investigated the effect of self-efficacy on goals in job search domain.

Keywords Self-efficacy, goals, job search behavior, job search effort, planning Paper type Research paper 
SELF-EFFICACY, GOALS AND JOB SEARCH BEHAVIORS

\section{Literature review}

\section{Social Cognitive Career Theory model}

"Self-efficacy" refers to the belief that one is capable of achieving one's goals. This concept has been studied in several domains, including cognition, health and counseling. In the latter, Lent, Brown and Hackett (1994) incorporated self-efficacy into a model they called Social Cognitive Career Theory (SCCT). Roughly speaking, this model postulates that self-efficacy influences personal goals, defined as an individual's intention to engage in a particular activity or to produce a particular outcome (Lent, 2005). Personal goals then determine the individual's actions, and these actions explain performance. The different paths of this model were validated in many studies.

In the investigation of the effect of self-efficacy on goals, authors used either selfefficacy to perform some activities (Sheu et al., 2010), either career decision self-efficacy (Ochs and Roessler, 2004), either job search self-efficacy (LaHuis, 2005; Van Hooft et al., 2004) and the assessment of goals varies across studies. Some authors used a questionnaire asking participants if they intend to perform some behaviors, like intention to engage in behaviors favorable to career management (Ochs and Roessler, 2004), intention to engage or persist in job search behaviors (LaHuis, 2005; Van Hooft et al., 2004). Others used a scale where the participant indicates for instance if "he has a clear set of goals for his(her) future"

(Rogers et al., 2008; Rogers and Creed, 2011). However, the path between self-efficacy and goals was confirmed, whatever the type of self-efficacy studied, the way of assessing goals and the sample used (students or job seekers).

Concerning the path between goals and actions, different actions were assessed, like planning behaviors (Rogers et al., 2008; Rogers and Creed, 2011), job search behaviors (Caska, 1998; Song et al., 2006; Wanberg et al., 2005; Zikic and Saks, 2009) or persistence in some academic majors (Lent et al., 2003). Moreover, job search behaviors are usually 


\section{SELF-EFFICACY, GOALS AND JOB SEARCH BEHAVIORS}

assessed from two angles: "intensity" (the frequency with which individuals use diverse search strategies) or "effort", in which case, they are asked how much effort they devote to looking for a job. As for the previous path, in all cases, studies highlighted the effect of goals on behaviors except for job search effort. Indeed, we don't know any study relative to the influence of goals on effort allocated to job search.

The path between action and performance was investigated for instance via the relationship between job search behaviors and success in finding a job. This effect has been found to be significant, but moderate in several studies (Saks and Ashforth, 1999; Wanberg et al., 1999), though not in all (Wanberg et al., 1996). Getting a job may also depend on other variables, like situational variables (Wanberg et al., 1996) and this would explain this result. No significant correlation has been found between effort and job search outcome (Brown et al., 2006; Saks and Ashforth, 1999, 2002). In return, it appears that career planning behaviors significantly determine employment quality (Zikic and Klehe, 2006; Saks and Ashforth, 2002).

These studies globally confirm Lent and Brown's model. However, the relevance of the path between action and performance seems to depend on the behaviors investigated (career planning vs job search behaviors). Furthermore, the assessment of goals varied across studies: some of them used intention to engage in some behaviors and others used scales rating different areas (Rogers et al., 2008; Rogers and Creed, 2011). This discrepancy questions the theoretical definition of goals.

\section{Self efficacy and job search}

Saks, Brown and Lent (2005) defined the role of goals in job searching, reviewing the variables empirically related to job search behaviors, then developing a causal model of these behaviors. In this model, individual difference variables (including job search self-efficacy) 


\section{SELF-EFFICACY, GOALS AND JOB SEARCH BEHAVIORS}

influence both job search goals and employment goals which, in turn, determine job search behaviors, while job search behaviors determine outcomes. "Job search goals" are defined as performance goals that individuals set themselves in their search (for instance sending out a certain number of applications each week) and "employment goals" refer to possible outcomes of their search, like obtaining a job.

This is an acknowledgement that career self-efficacy contributes to the setting of goals and that goals contribute to performance, but how? For his part, Bandura (1997) considers that goals must be specific if they are to have a motivating effect. According to Earley, Wojnaroski and Prest (1987), a specific goal favors planning behavior because it is easier for the individual to anticipate the most appropriate behavior. This feature of goals was investigated in job search domain only through job search clarity (defined as the extent to which job seekers have precise objectives for the type of work they want). In these studies, job search clarity was assessed by a scale where the participants indicated if they had clear objectives (Côté, Saks and Zikic, 2006; Zikic and Saks, 2009). Côté, Saks and Zikic (2006) showed that job search clarity mediates the effect of self-efficacy on job search intensity and Zikic and Saks (2009) observed a significant relationship between self-efficacy and job search clarity, and a significant effect of clarity on job search intensity. However, job search clarity does not seem to assess nor employment goals, nor job search goals, as defined by Saks et al. (2005).

It should be mentioned that in many studies, the effect of job search self-efficacy on behaviors is assumed to be direct. Zikic and Klehe (2006) found an effect of self-efficacy on career planning. Concerning the effect of job search self-efficacy on job search intensity, results are divergent. Saks and Ashforth (1999) and Wanberg, Kanfer and Rotundo (1999) obtained significant effects, unlike Wanberg, Watt and Rumsey (1996). The observed difference may be due to the use of different samples. Wanberg et al. (1996) conducted their 


\section{SELF-EFFICACY, GOALS AND JOB SEARCH BEHAVIORS}

study on participants who were being laid off. Hence, their self-efficacy level may have been lowered by their situation and thus, would not have a revitalizing effect. Studies of the effect of job search self-efficacy on effort have also yielded inconsistent results. Some of them have reported a significant effect (Saks and Ashforth, 1999; Saks, 2006), whereas others have not (Brown et al., 2006; Saks and Ashforth, 2000), but the obtained correlations were always moderate.

The aim of this study was to validate a model inspired of the models elaborated by Lent and Brown and by Saks, Brown and Lent. Our model includes several variables, job search self-efficacy, goal employment, planning behaviors, job search behaviors and job search effort. This model is displayed in Figure 1:

Insert Figure 1 here

Our model postulates that precision of the employment goal would mediate the relationships between job search self-efficacy and diverse behaviors related to job search, like job search planning, job search behaviors and effort allocated to job search. Models elaborated by Lent and Brown and by Saks, Brown and Lent both postulate that self-efficacy determines goals and that goals determine diverse behaviors. Moreover, Bandura (1997) specifies what features of goals are supposed to be influenced by self-efficacy and considers that specificity of the goal is a relevant feature. Thus, we supposed that a high level of job search self-efficacy would result in a search for a very specific job (i.e. in a specific goal employment) and that a specific goal employment would determine diverse behaviors. Concerning the behaviors supposed to be influenced by goals, as we study job search self-efficacy and employment goals, we chose both measures of job search behaviors. Moreover, a specific goal is supposed to entail planning behaviors (Earley et al., 1987), so, we introduced job search planning in our model.

\section{Method}




\section{SELF-EFFICACY, GOALS AND JOB SEARCH BEHAVIORS}

Sample. One hundred participants (54 men, 44 women and 2 participants who did not indicate their gender) took part in this study. Participants ranged in age from 16 to 61 years $(M=36.6$, $S D=11.70)$. Their education level varied from 6 to 20 years $(M=13, S D=2.80) .78$ were unemployed, 15 were employed, 3 were student and 4 of them did not indicate their status. Participants had been looking for a job for a mean period of 18 months ( $S D=20.91$ months). For those who were unemployed, their jobless duration varied between one day and 10 years. Procedure. Participants were recruited at two centers offering help to job seekers (the Cité des Métiers and an agency of the Pôle Emploi). Only volunteers were given the questionnaires and completed them on the spot.

\section{Measures}

Job search self-efficacy. We chose to administer the Career Search Efficacy Scale (CSES) developed by Solberg et al. (1994). This scale contains 35 items rating the participant's confidence in his or her ability to perform tasks related to the job search. This scale has proven to be psychometrically sound (Solberg et al., 1994). After translating this scale into French, we decided to reject two of the items, as they did not seem relevant in the French context. Participants answered using a 10-point Likert-type scale (ranging from 0 to 9) according to their level of confidence in doing what was described by the item. Internal consistency, as measured by Cronbach's alpha, was .97. Hence, we computed a global score. A high score describes a strong confidence of the participant in his ability to perform activities.

Employment goal. As this variable has rarely been investigated, we had to create a measure. We used an open question to assess this variable. Participants were asked to say what sort of job they were looking for and to give as many details as possible (type of contract, full- or part-time job, and geographical area). 
SELF-EFFICACY, GOALS AND JOB SEARCH BEHAVIORS

Job search behaviors. The questionnaire used in this study was inspired by the scale developed by Blau (1993). We adapted Blau's items in order to make them more relevant in the French context and to introduce new job search strategies into the scale (e.g., use of the Internet). Fourteen behaviors were presented to participants, who were asked to indicate how often they had performed these behaviors within the previous month on a 5-point scale (from "Never" to "Very often"). Cronbach's alpha was .84. A higher score indicates a more frequent use of job search behaviors.

Planning behaviors. This scale consists of twelve job search behaviors. For each of them, the participant must indicate to what extent he recently planned to perform the behavior on a 5point scale (from "Never" to "Very often"). Cronbach's alpha was .83. A high score means that the participant frequently plans his search.

Effort allocated to job search. Participants were also asked to indicate how much time they had devoted to looking for a job over the previous two weeks. The answer to this question enabled us to rate job search effort.

Control variables. As significant effects of education level, age and jobless duration had been observed on job search behaviors in previous studies (Kulik, 2001; Wanberg et al., 2000), we added a measure of these variables in order to control for their influence.

\section{Results}

\section{Preliminary analysis}

Before testing our hypotheses, a preliminary study was conducted to rate the precision of the participants' goals. We conducted a content analysis of their answers to this question. We first read the answers given by the participants and distinguished four levels of precision according to the details they provided. These levels are illustrated by the following examples:

- Very undefined goal: going back to work and setting up my own business;

- Undefined goal: setting up my own business in the building trade; 
SELF-EFFICACY, GOALS AND JOB SEARCH BEHAVIORS

- Precise goal: becoming a full-time nurse's aide in a nursing home with an open-ended contract;

- Very precise goal: care assistant for the elderly, in the South of France, working nights, room and board during the week.

Then, three raters (the authors of this study) were provided a definition of each precision level and tried to categorize the answers according to the levels of precision. Inter rater agreement was very high (95\%). In case of disagreement, we categorized the answer according to the precision level given by a majority of coders. This first step allowed us to rate goal precision from 1 to 4 . When participants cited several employment goals, we rated the precision of each of them and then computed a mean goal precision score for that participant.

Insert Table 1 here

Correlations and descriptive statistics are displayed in Table 1. Some control variables are correlated with the studied variables (age with effort allocated to job search, education level with goal precision). Variables related to self-efficacy and behaviors are also correlated. Hypotheses testing

To test our model, we followed the procedure described by Baron and Kenny (1986). These authors consider that a variable mediates the path between a predictor and a criterion if it meets the following conditions. Predictor (job search self-efficacy) significantly influences mediator variable (precision of the employment goal). Predictor determines criterion (respectively planning behaviors, job search behaviors and effort devoted to job search). Mediator variable significantly influences criterion. The path between predictor and criterion is significantly reduced when mediator is introduced in regression. Each of these conditions is tested by regressions performed on planning behaviors, job search behaviors and effort 
SELF-EFFICACY, GOALS AND JOB SEARCH BEHAVIORS

devoted to job search. Moreover, we introduced jobless duration, education level and age as predictors to partial out the effect of these variables.

Results are displayed in Table 2

\section{Insert Table 2}

The first condition to consider that precision of the employment goal mediates the effect of job search self-efficacy on behaviors is not satisfied. Thus, results of step 1 indicated that job search self-efficacy did not significantly influence precision of employment goal. At step 2, it appears that the effect of predictor (job search self-efficacy) on criterion varied according to the criterion considered. This effect was significant for planning behaviors and job search behaviors, but not for effort devoted to job search. Results at step 3 indicate that the mediator variable (precision of the employment goal) did not significantly influence criterion (planning behaviors, job search behaviors and effort devoted to job search). Step 4 shows that job search self-efficacy significantly influenced job search behaviors and planning behaviors even if we introduce the mediator variable in regression. This result was observed for planning behaviors and job search behaviors, not for effort allocated to job search.

Overall, our hypotheses were not confirmed: goal precision was not explained by job search self-efficacy and determined neither behaviors nor the amount of time devoted to search. By contrast, self-efficacy directly influenced planning and job search behaviors. Our results therefore invalidate our model, at least in terms of goal precision.

\section{Discussion}

In this study, we developed a model of relationships between job-search variables, inspired by Lent and Brown's model and Saks et al. (2005) review. Several scales were used to assess these variables and administered to a sample of participants, and the relationships of the model were then tested. 
SELF-EFFICACY, GOALS AND JOB SEARCH BEHAVIORS

Contrary to expectations, self-efficacy did not have a significant effect on goal employment precision. Self-efficacy theory postulates that a high level of self-efficacy entails the setting of clearly defined goals. However, in the job search domain, goal precision has only been investigated by Côté et al. (2006) and Zikic and Saks (2009), who refer to it as "job search clarity". In these two studies, job search clarity was either explained by or correlated with self-efficacy. However, it was assessed by questionnaires where respondents were asked if they had a clear vision of their search and we believe that this is not a relevant way of assessing goal precision. It is a subjective measure and its use implies that individuals are able to rate the precision of their own goals. Furthermore, answers to this questionnaire risk being biased by social desirability and there is no way of checking that they match the actual goals. The goal precision assessment method we adopted in this study seemed to correspond more closely to the theoretical definition. We considered that the participants' goal was to find a job and that we could therefore assess the precision of this goal by asking them what job they were looking for, requesting as many details as possible. Goal precision was then rated by the experimenters. This difference in the methods used to assess goal precision could thus explain the divergent results.

The relevance of our hypothesis is also open to question. Koen, Klehe, Van Vianen, Zikic and Nauta (2010) postulated that job seekers alternate between different strategies (exploratory, focused and haphazard), that the use of a focused strategy is determined by clear employment goals and that the effect of self-efficacy on strategies varies according to the strategy being considered. Moreover, according to Koen et al. (2010), self-efficacy and employment goals conjointly determine the use of strategies, whereas in Lent and Brown's model, self-efficacy determines goals.

Planning behaviors, job search behaviors and effort devoted to job search were not significantly influenced by goal precision. Concerning the effect of goals on job search 


\section{SELF-EFFICACY, GOALS AND JOB SEARCH BEHAVIORS}

behaviors, our results again contradict those obtained by Côté et al. (2006) and Zikic and Saks (2009), who found an effect of job search clarity on job search intensity. The nonsignificant effect of employment goals on job search behaviors in our study may once more have been due to the way we assessed goal precision. Concerning planning behaviors, some studies have investigated career planning behaviors, rather than job search planning behaviors. However, as we can assume that the goal of our participants was to find a job, we chose to focus on job search planning because it seemed to us that these behaviors might help participants to attain their goal. Locke and Latham (2002) observed that in the case of a new task, people plan the actions needed to attain their goals. Accordingly, goals determine the use of planning behaviors. If we regard job search as a new task, we can assume that the goal has an effect on planning behaviors. However, the status of planning behaviors varies from study to study. According to Zikic and Klehe (2006) and Rogers et al. (2008), planning behaviors are determined by self-efficacy, whereas Koen et al. (2010) hold that self-efficacy and planning behaviors together influence job search strategies.

Concerning the amount of effort devoted to job search, in their meta-analysis, Kanfer, Wanberg and Kantrowitz (2001) reported variable correlations between job search behaviors and their antecedents, according to the way in which the former were assessed (intensity or effort). They concluded that these two types of variables did not entirely overlap, as indicated by the correlations between them (Brown et al., 2006; Saks, 2006; Saks and Ashforth, 2002). Furthermore, in these studies, effort was assessed by a questionnaire where respondents had to indicate the degree to which job search represented an effort. In other studies, authors have investigated either the amount of time spent on job search (Kulik, 2000, 2001; Wanberg et al., 2010), as we did, or else the amount of time spent implementing one specific strategy (Hoye et al., 2009), but have not studied the paths between these variables and job search self- 


\section{SELF-EFFICACY, GOALS AND JOB SEARCH BEHAVIORS}

efficacy or employment goals. We deemed that assessing effort via the amount of time devoted to job search was a more valid method and less susceptible to social desirability bias.

However, as in previous studies (Saks and Ashforth, 1999; Wanberg et al., 1999), job search behaviors and planning behaviors were directly determined by self-efficacy. In return the effect of job search self-efficacy on effort devoted to job search was not significant. Previous results relative to the effect of job search self-efficacy on effort are inconsistent. Saks (2006) observed a significant correlation contrary to Brown et al (2006). Moreover, in these studies, effort is assessed by a scale and not by the amount of time spent to search. Thus, the divergent ways of assessing effort can partially explain these inconsistent results.

Our results invalidated our model, insofar as goal precision did not appear to be an intermediate variable between self-efficacy, planning and job search behaviors. Nevertheless, self-efficacy directly influenced both types of behaviors. This result can be interpreted in two ways: either employment goals are related neither to job search self-efficacy nor to planning and job search behaviors, or goal precision is not the relevant feature of goals. Self-efficacy is also supposed to determine the level of performance : a high level of self-efficacy entails difficult performance goals (Lent, 2005). The effect of self-efficacy on the goal's level of difficulty has been highlighted in previous studies. Bandura and Wood (1989) observed an effect of self-efficacy on the performance goals that participants set themselves. That said, the way that goal difficulty levels would be assessed in counseling is questioned, as the same employment goal may represent different levels of difficulty, according to individual profiles (education level, jobless duration, etc.).

\section{Contributions of Research}

This study is original for several reasons. Some reasons are methodological and are relative to the way of assessing employment goals and effort devoted to job search. Indeed, the measures of these concepts used in previous studies did not seem valid and we chose new measures to 


\section{SELF-EFFICACY, GOALS AND JOB SEARCH BEHAVIORS}

assess these variables. Other reasons are theoretical. To our knowledge, planning behaviors were never investigated in job search and employment goals were rarely studied. Thus, this enabled us to elaborate and to test an original model. However, our results showed that, using these measures of employment goal and effort devoted to job search, precision of the employment goal does not mediate the path between job search self-efficacy, job search behaviors and job search planning and that effort devoted to job search was not determined by any variable of our model.

\section{Limitations of the study}

Our results and the examination of previous studies raise theoretical and methodological questions. The first question is related to the role of self-efficacy, planning behaviors and strategies: does self-efficacy influence planning behaviors or do these concepts independently determine strategies? At a methodological level, an examination of the correlation matrix revealed strong correlations between the variables assessed by the different scales (job search self-efficacy, planning behaviors and job search behaviors). Hence, the use of similarly constructed scales to assess these variables may have resulted in closer correlations. In the same vein, the inconsistent results yielded by previous studies in relation to job search behaviors (Saks and Ashforth, 1999; Wanberg et al., 1999; Wanberg et al., 1996) and job search clarity (Côté et al., 2006; Zikic and Saks, 2009) may have stemmed from differences in assessment choices. Thus, further studies are needed to investigate the relationships between these different tools.

The results of this study open up several avenues for future research. Although this study shed light on relationships between some of the variables, it provided no information about concrete results, that is to say, whether or not participants subsequently found a job. To do so, a two-wave study would be necessary. Self-efficacy and job search behaviors could be assessed at the outset and the participants' status at a later point. The relationship between 


\section{SELF-EFFICACY, GOALS AND JOB SEARCH BEHAVIORS}

self-efficacy and goals needs to be investigated in greater depth. Self-efficacy is supposed to entail ambitious goals, but this is a very subjective characteristic. Participants could therefore indicate the degree to which their goals seem ambitious to them. We could also investigate the performance goals that individuals set themselves in their job search by asking them what performance levels they want to attain within a given time (e.g., how many companies to call, how many job offers to answer, etc.). It also seems relevant to distinguish between different job search strategies. As Koen et al. (2010) suggested, the effect of self-efficacy may vary according to the type of strategy that is implemented. Thus, examining the effects of selfefficacy on each type of strategy would enable us to hone our results.

\section{Implications for practice}

As job search self-efficacy positively contributes to planning behaviors and job search behaviors, it appears necessary to develop interventions in order to lower job search selfefficacy. Such interventions exist, they are designed to promote job search self-efficacy (Creed et al., 2001), or more globally career self-efficacy (Fouad et al., 2009; Scott and Ciani, 2008). Self-efficacy is stimulated via performance accomplishments (i.e. the learning of skills related to job search or career decision) and via verbal persuasion (i.e. support provided by the instructor). In return, our results also indicate that, in such interventions, it is not necessary to lead participants to elaborate very specific employment goals as these goals don't have a motivating effect. 
SELF-EFFICACY, GOALS AND JOB SEARCH BEHAVIORS

\section{References}

Bandura, A. (1997), Self-efficacy: The exercise of control, W H Freeman/Times Books/ Henry Holt \& Co, New York, NY US.

Bandura, A. and Wood, R. (1989), "Effect of perceived controllability and performance standards on self-regulation of complex decision making", Journal of Personality and Social Psychology, Vol. 56 No 5, pp. 805-814.

Baron, R. M. and Kenny, D. A. (1986), "The moderator-mediator variable distinction in social psychological research: Conceptual, strategic, and statistical considerations", Journal of Personality and Social Psychology, Vol. 51 No 6, pp. 1173-1182.

Blau, G. (1993), "Further exploring the relationship between job search and voluntary individual turnover", Personnel Psychology, Vol. 46 No 2, pp. 313-330.

Brown, D. J., Cober, R. T., Kane, K., Levy, P. E. and Shalhoop, J. (2006), "Proactive personality and the successful job search: A field investigation with college graduates", Journal of Applied Psychology, Vol. 91 No 3, pp. 717-726.

Caska, B. A. (1998), "The search for employment: Motivation to engage in a coping behavior", Journal of Applied Social Psychology, Vol. 28 No 3, pp. 206-224.

Côté, S., Saks, A. M. and Zikic, J. (2006), "Trait affect and job search outcomes", Journal of Vocational Behavior, Vol. 68 No 2, pp. 233-252.

Creed, P. A., Bloxsome, T. D. and Johnston, K. (2001), "Self-esteem and self-efficacy outcomes for unemployed individuals attending occupational skills training programs", Community, Work \& Family, Vol. 4 No 3, pp. 285-303.

Earley, P. C., Wojnaroski, P. and Prest, W. (1987), "Task planning and energy expended: Exploration of how goals influence performance", Journal of Applied Psychology, Vol. 72 No 1, pp. 107-114. 
SELF-EFFICACY, GOALS AND JOB SEARCH BEHAVIORS

Fouad, N., Cotter, E. W. and Kantamneni, N. (2009), "The effectiveness of a career decisionmaking course", Journal of Career Assessment, Vol. 17 No 3, pp. 338-347.

Hoye, G. V., Van Hooft, E. a. J. and Lievens, F. (2009), "Networking as a job search behaviour: A social network perspective", Journal of Occupational and Organizational Psychology, Vol. 82 No 3, pp. 661-682.

Kanfer, R., Wanberg, C. R. and Kantrowitz, T. M. (2001), "Job search and employment: A personality-motivational analysis and meta-analytic review", Journal of Applied Psychology, Vol. 86 No 5, pp. 837-855.

Koen, J., Klehe, U.-C., Van Vianen, A. E. M., Zikic, J. and Nauta, A. (2010), "Job-search strategies and reemployment quality: The impact of career adaptability", Journal of Vocational Behavior, Vol. 77 No 1, pp. 126-139.

Kulik, L. (2000), "Jobless men and women: A comparative analysis of job search intensity, attitudes toward unemployment and related responses", Journal of Occupational and Organizational Psychology, Vol. 73 No 4, pp. 487-500.

Kulik, L. (2001), "Impact of length of unemployment and age on jobless men and women: A comparative analysis", Journal of Employment Counseling, Vol. 38 No 1, pp. 15-27.

Lahuis, D. M. (2005), "Individual Differences in Applicant Reactions: A Job-Search Perspective", International Journal of Selection and Assessment, Vol. 13 No 2, pp. 150-159.

Lent, R. W. (2005), "A Social Cognitive View of Career Development and Counseling", in Brown, S. D. \& Lent, R. W. (eds.), Career development and counseling: Putting theory and research to work., John Wiley \& Sons Inc, Hoboken, NJ US, pp. 101-127.

Lent, R. W., Brown, S. D. and Hackett, G. (1994), "Toward a unifying social cognitive theory of career and academic interest, choice, and performance", Journal of Vocational Behavior, Vol. 45 No 1, pp. 79-122. 
SELF-EFFICACY, GOALS AND JOB SEARCH BEHAVIORS

Lent, R. W., Brown, S. D., Schmidt, J., Brenner, B., Lyons, H. and Treistman, D. (2003), "Relation of contextual supports and barriers to choice behavior in engineering majors: Test of alternative social cognitive models", Journal of Counseling Psychology, Vol. 50 No 4, pp. 458-465.

Locke, E. A. and Latham, G. P. (2002), "Building a practically useful theory of goal setting and task motivation: A 35-year odyssey", American Psychologist, Vol. 57 No 9, pp. 705-717.

Ochs, L. A. and Roessler, R. T. (2004), "Predictors of Career Exploration Intentions: A Social Cognitive Career Theory Perspective", Rehabilitation Counseling Bulletin, Vol. 47 No 4, pp. 224-233.

Rogers, M. E. and Creed, P. A. (2011), "A longitudinal examination of adolescent career planning and exploration using a social cognitive career theory framework", Journal of Adolescence, Vol. 34 No 1, pp. 163-172.

Rogers, M. E., Creed, P. A. and Glendon, A. I. (2008), "The role of personality in adolescent career planning and exploration: A social cognitive perspective", Journal of Vocational Behavior, Vol. 73 No 1, pp. 132-142.

Saks, A. M. (2006), "Multiple predictors and criteria of job search success", Journal of Vocational Behavior, Vol. 68 No 3, pp. 400-415.

Saks, A. M. and Ashforth, B. E. (1999), "Effects of individual differences and job search behaviors on the employment status of recent university graduates", Journal of Vocational Behavior, Vol. 54 No 2, pp. 335-349.

Saks, A. M. and Ashforth, B. E. (2000), "Change in job search behaviors and employment outcomes", Journal of Vocational Behavior, Vol. 56 No 2, pp. 277-287.

Saks, A. M. and Ashforth, B. E. (2002), "Is job search related to employment quality? It all depends on the fit", Journal of Applied Psychology, Vol. 87 No 4, pp. 646-654. 
SELF-EFFICACY, GOALS AND JOB SEARCH BEHAVIORS

Saks, A. M., Brown, S. D. and Lent, R. W. (2005), "Job Search Success: A Review and Integration of the Predictors, Behaviors, and Outcomes", in Brown, S. D. \& Lent, R. W. (eds.), Career development and counseling: Putting theory and research to work., John Wiley \& Sons Inc, Hoboken, NJ US, pp. 155-179

Scott, A. B. and Ciani, K. D. (2008), "Effects of an undergraduate career class on men's and women's career decision-making self-efficacy and vocational identity", Journal of Career Development, Vol. 34 No 3, pp. 263-285.

Sheu, H.-B., Lent, R. W., Brown, S. D., Miller, M. J., Hennessy, K. D. and Duffy, R. D. (2010), "Testing the choice model of social cognitive career theory across Holland themes: A meta-analytic path analysis", Journal of Vocational Behavior, Vol. 76 No 2, pp. 252-264.

Solberg, V. S., Good, G. E., Nord, D., Holm, C., Hohner, R., Zima, N., Heffernan, M. and Malen, A. (1994), "Assessing career search expectations: Development and validation of the Career Search Efficacy Scale", Journal of Career Assessment, Vol. 2 No 2, pp. 111-123.

Song, Z., Wanberg, C., Niu, X. and Xie, Y. (2006), "Action-state orientation and the theory of planned behavior: A study of job search in China", Journal of Vocational Behavior, Vol. 68 No 3, pp. 490-503.

Van Hooft, E. a. J., Born, M. P., Taris, T. W., Van Der Flier, H. and Blonk, R. W. B. (2004), "Predictors of Job Search Behavior Among Employed and Unemployed People", Personnel Psychology, Vol. 57 No 1, pp. 25-59.

Wanberg, C. R., Glomb, T. M., Song, Z. and Sorenson, S. (2005), "Job-Search Persistence During Unemployment: A 10-Wave Longitudinal Study", Journal of Applied Psychology, Vol. 90 No 3, pp. 411-430. 
SELF-EFFICACY, GOALS AND JOB SEARCH BEHAVIORS

Wanberg, C. R., Kanfer, R. and Banas, J. T. (2000), "Predictors and outcomes of networking intensity among unemployed job seekers", Journal of Applied Psychology, Vol. 85 No 4, pp. 491-503.

Wanberg, C. R., Kanfer, R. and Rotundo, M. (1999), "Unemployed individuals: Motives, jobsearch competencies, and job-search constraints as predictors of job seeking and reemployment", Journal of Applied Psychology, Vol. 84 No 6, pp. 897-910.

Wanberg, C. R., Watt, J. D. and Rumsey, D. J. (1996), "Individuals without jobs: An empirical study of job-seeking behavior and reemployment", Journal of Applied Psychology, Vol. 81 No 1, pp. 76-87.

Wanberg, C. R., Zhu, J. and Van Hooft, E. a. J. (2010), "The job search grind: Perceived progress, self-reactions, and self-regulation of search effort", Academy of Management Journal, Vol. 53 No 4, pp. 788-807.

Zikic, J. and Klehe, U.-C. (2006), "Job loss as a blessing in disguise: The role of career exploration and career planning in predicting reemployment quality", Journal of Vocational Behavior, Vol. 69 No 3, pp. 391-409.

Zikic, J. and Saks, A. M. (2009), "Job search and social cognitive theory: The role of careerrelevant activities", Journal of Vocational Behavior, Vol. 74 No 1, pp. 117-127. 
SELF-EFFICACY, GOALS AND JOB SEARCH BEHAVIORS

\section{Appendix}

Figure 1

Hypothetical model of relationships between job search self-efficacy, employment goal, job search behaviors, effort devoted to job search and job search planning

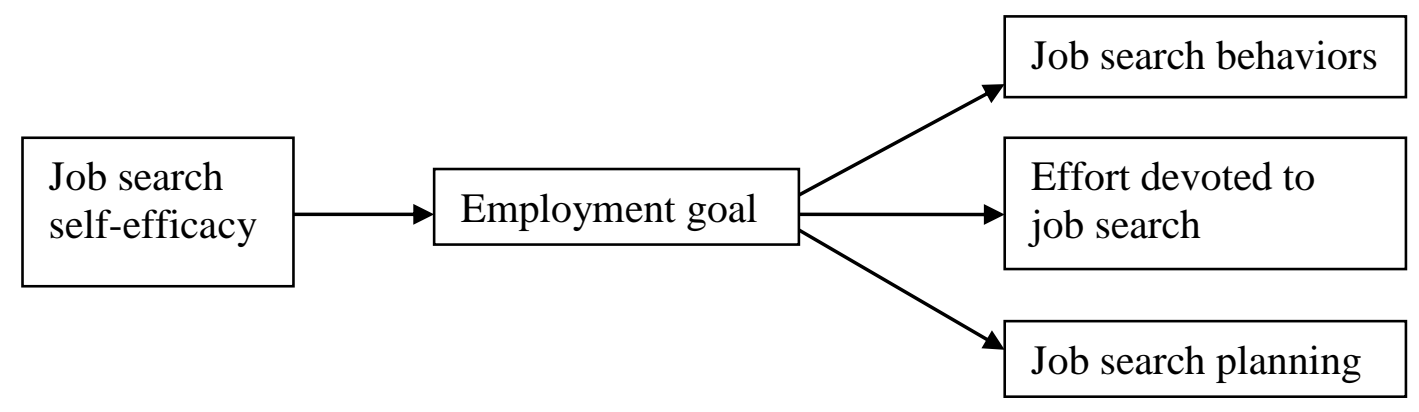


SELF-EFFICACY, GOALS AND JOB SEARCH BEHAVIORS

Survey scale measures and sample items

Job search self-efficacy

How confident are you in your ability to:

1. Identify and evaluate your career values.

2. Meet new people in careers of interest.

Employment goal

Do you have one or several professional plans?

If you have a professional plan, provide the following information about the job you would

like to find:

Branch of industry:

Professional environment (company, association...):

Geographical area:

Working conditions (type of contract, full- or part-time job):

Planning behaviors

Carefully read each of the following sentences and indicate to what extent you planned and organized these activities in order to achieve your plans.

1. Identify potential employers or firms that could hire you.

2. Assist to workshops to help you to search.

Job search behaviors

How frequently did you engage in the following behaviors during the last month?

1. Read the help wanted/classified ads in a newspaper, journal or on the Web.

2. Talk with friends or relatives about possible job leads.

Effort allocated to job search

How many hours did you devote to job search over the previous two weeks? 
SELF-EFFICACY, GOALS AND JOB SEARCH BEHAVIORS

Table 1

Descriptive statistics and correlation matrix

\begin{tabular}{|c|c|c|c|c|c|c|c|c|c|}
\hline & $M$ & $S D$ & 1 & 2 & 3 & 4 & 5 & 6 & 7 \\
\hline 1. Goal precision & 2.32 & 0.79 & & & & & & & \\
\hline 2. Effort devoted to search & 15.41 & 10.92 & -.123 & & & & & & \\
\hline 3. Age & 36.58 & 11.70 & -.191 & $.221 *$ & & & & & \\
\hline 4. Jobless duration & 18.15 & 20.91 & -.215 & -.057 & $.288 * *$ & & & & \\
\hline 5. Education level & 12.98 & 2.80 & $.233 *$ & -.008 & -.013 & -.094 & & & \\
\hline 6. Job search self-efficacy & 191.45 & 49.93 & .044 & -.008 & .130 & $-.254 *$ & .126 & & \\
\hline 7. Planning behaviors & 39.68 & 10.00 & -.075 & .147 & .177 & $-.241 *$ & .011 & $.667 * *$ & \\
\hline 8. Job search behaviors & 42.18 & 11.37 & -.036 & $.255^{*}$ & -.015 & -.213 & -.145 & $.523 * *$ & $.570 * *$ \\
\hline
\end{tabular}


SELF-EFFICACY, GOALS AND JOB SEARCH BEHAVIORS

Table 2

Results of the regressions conducted on planning behaviors, job search behaviors and effort devoted to job search

\begin{tabular}{|c|c|c|c|c|c|c|c|c|c|}
\hline \multirow[t]{2}{*}{ Criteria } & \multicolumn{3}{|c|}{ Planning behaviors } & \multicolumn{3}{|c|}{ Job search behaviors } & \multicolumn{3}{|c|}{ Effort devoted to job search } \\
\hline & $R^{2}$ & $\Delta R^{2}$ & Beta & $R^{2}$ & $\Delta R^{2}$ & Beta & $R^{2}$ & $\Delta R^{2}$ & Beta \\
\hline \multicolumn{10}{|l|}{ Step 1} \\
\hline Jobless duration & .05 & & -.21 & .05 & & -.21 & .05 & & -.21 \\
\hline Education level & $.05^{*}$ & & $.23^{*}$ & $.05^{*}$ & & $.23^{*}$ & $.05^{*}$ & & $.23^{*}$ \\
\hline Age & .04 & & -.19 & .04 & & -.19 & .04 & & -.19 \\
\hline Self-efficacy & .01 & & .04 & .01 & & .04 & .01 & & .04 \\
\hline \multicolumn{10}{|l|}{ Step 2} \\
\hline Jobless duration & $.06^{*}$ & & $-.24 *$ & .05 & & -.21 & .01 & & -.06 \\
\hline Education level & .01 & & .01 & .02 & & -.15 & .01 & & -.01 \\
\hline Age & .03 & & .18 & .01 & & -.02 & .05 & & $.22 *$ \\
\hline Self-efficacy & $.44 * * *$ & & $.67 * * *$ & $.27 * * *$ & & $.52 * * *$ & .01 & & -.01 \\
\hline Step 3 & $.13^{*}$ & & & .10 & & & .09 & & \\
\hline Jobless duration & & & $-.24 *$ & & & $-.30^{*}$ & & & -.14 \\
\hline Education level & & & .09 & & & -.11 & & & -.07 \\
\hline Age & & & $.32 *$ & & & .15 & & & $.28 *$ \\
\hline Goal precision & & & -.11 & & & -.01 & & & -.03 \\
\hline Step 4 & $.65^{* * *}$ & .52 & & $.37 * * *$ & .27 & & .09 & .00 & \\
\hline Jobless duration & & & -.08 & & & -.19 & & & -.16 \\
\hline Education level & & & -.04 & & & $-.21^{*}$ & & & -.06 \\
\hline Age & & & .06 & & & -.04 & & & $.31 *$ \\
\hline Goal precision & & & -.14 & & & -.03 & & & -.03 \\
\hline Self-efficacy & & & $.77 * * *$ & & & $.56^{* * *}$ & & & -.08 \\
\hline
\end{tabular}

$* p<.05, * * p<.01, * * * p<.001$ 